\title{
IMAGES OF LAST MOUNTAIN LAKE
}

Compiled by G.W. BEYERSBERGEN and P.S. TAYLOR, Canadian Wildlife Service, Saskatoon, Saskatchewan. S7N OX4

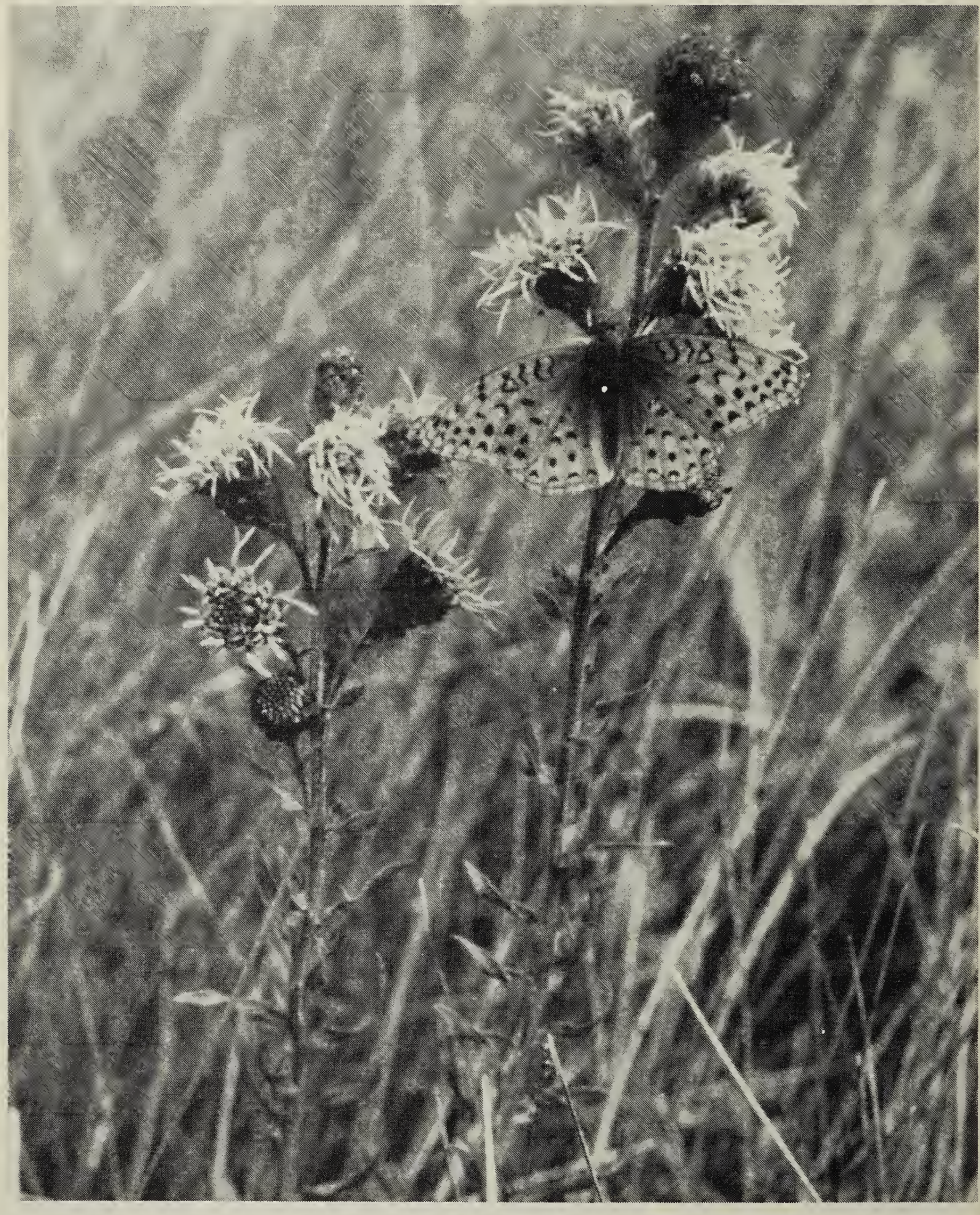

P.S. Taylor

Often, whole acres would be red and purple with beautiful flowers and the air laden with the perfume of roses.

- J.A. Macoun, from his journal, $1879 .^{3}$ 


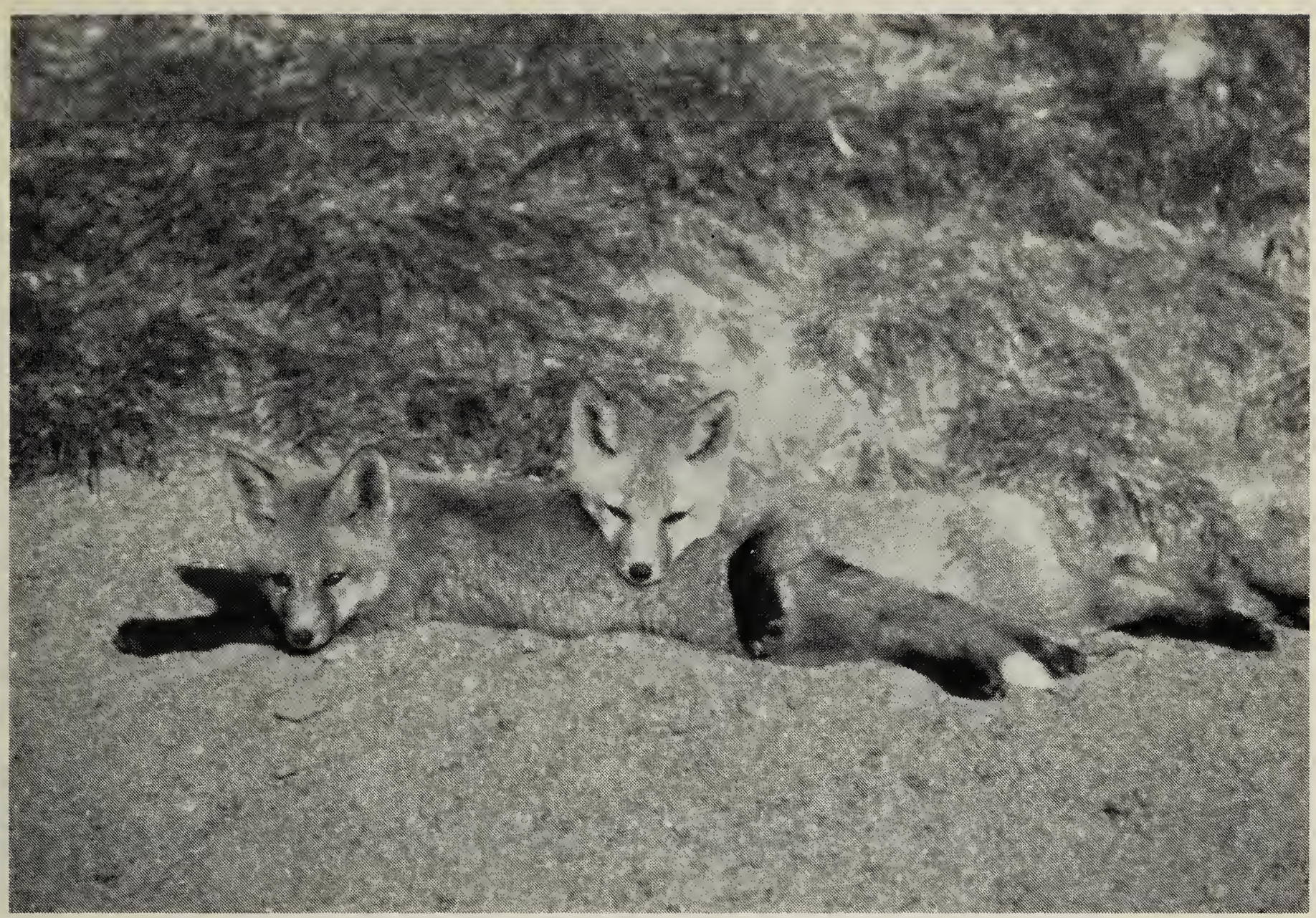

G.W. Beyersbergen

Man has nothing that the animals have not at least a vestige of, the animals have nothing that man does not in some degree share.

- Ernest Thompson Seton, 1898. ${ }^{4}$

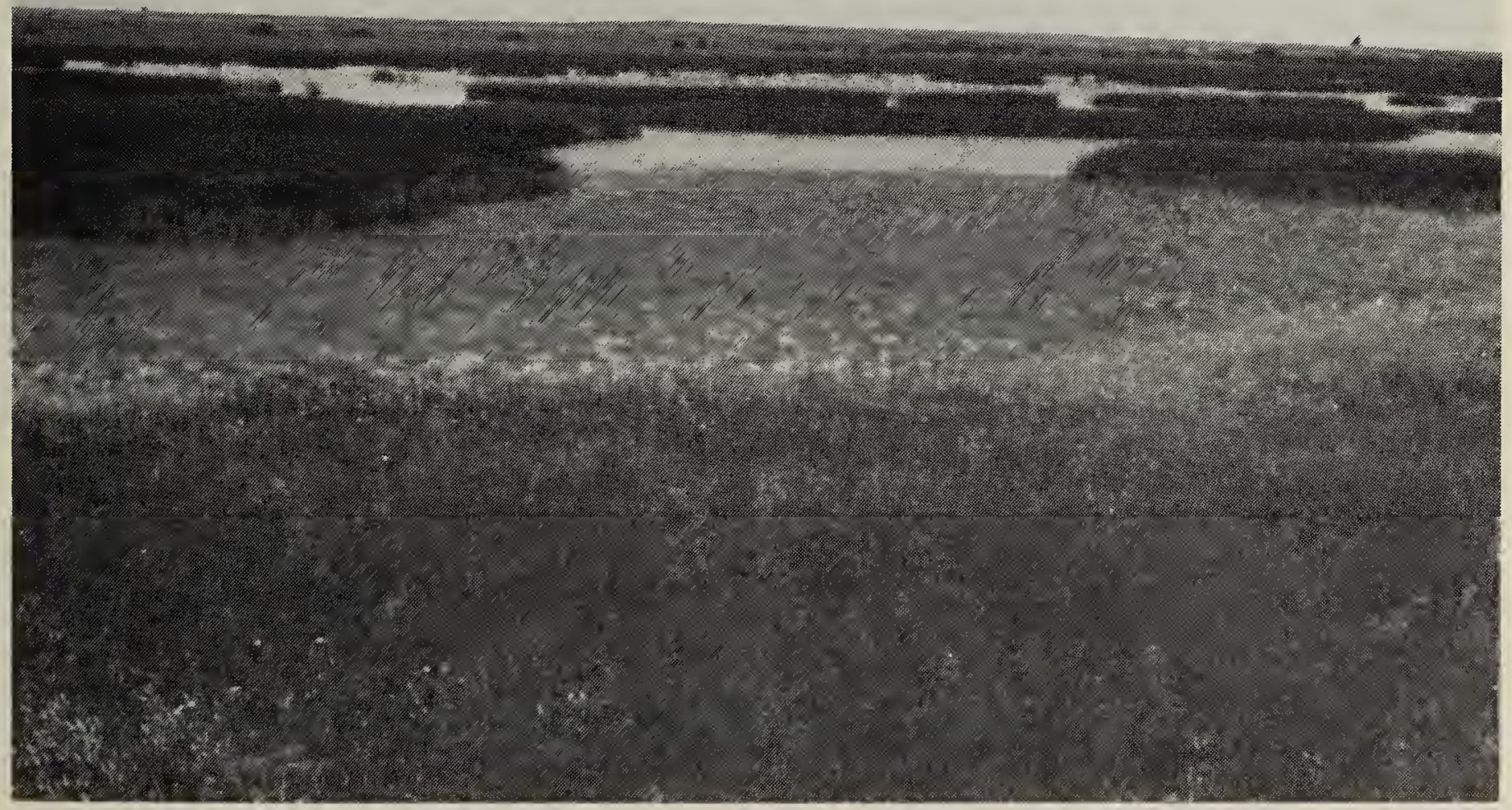




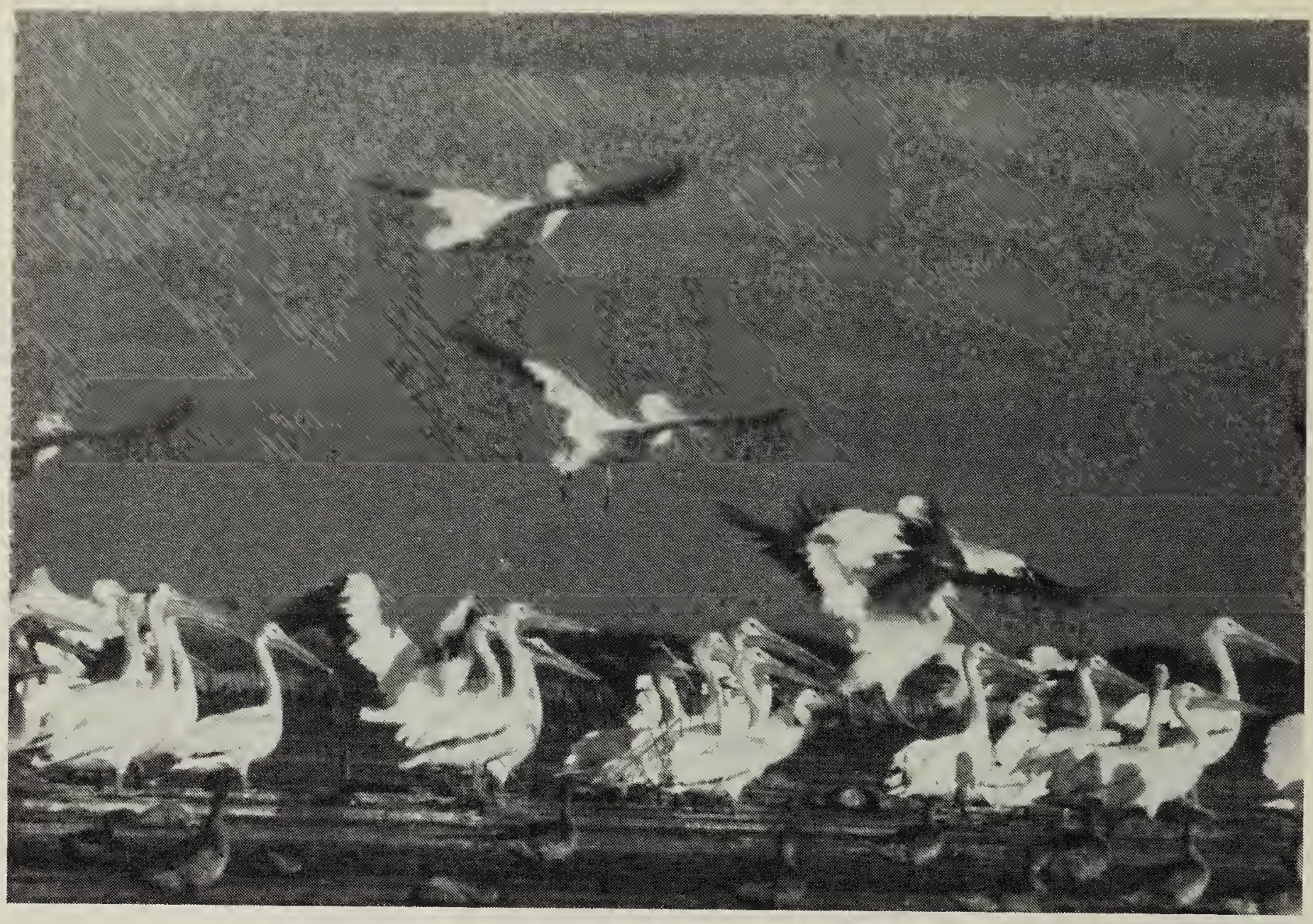

G.W. Beyersbergen

The grass, the swamps and the lakeshore are alive with birds. ... All this in the wide prairie land, which so many people think dull and.uninteresting.

- R.D. Symons, $1967 .{ }^{5}$

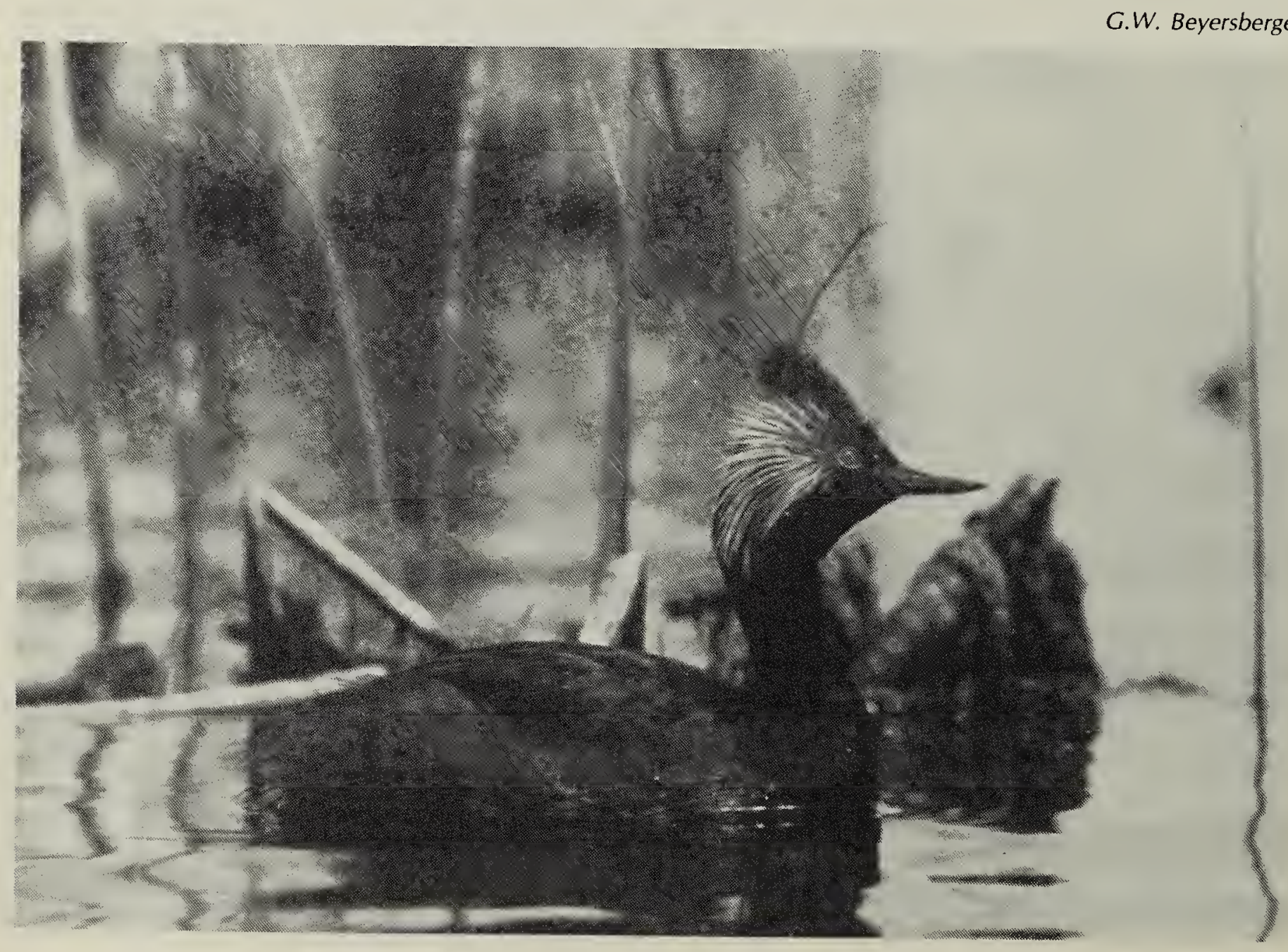




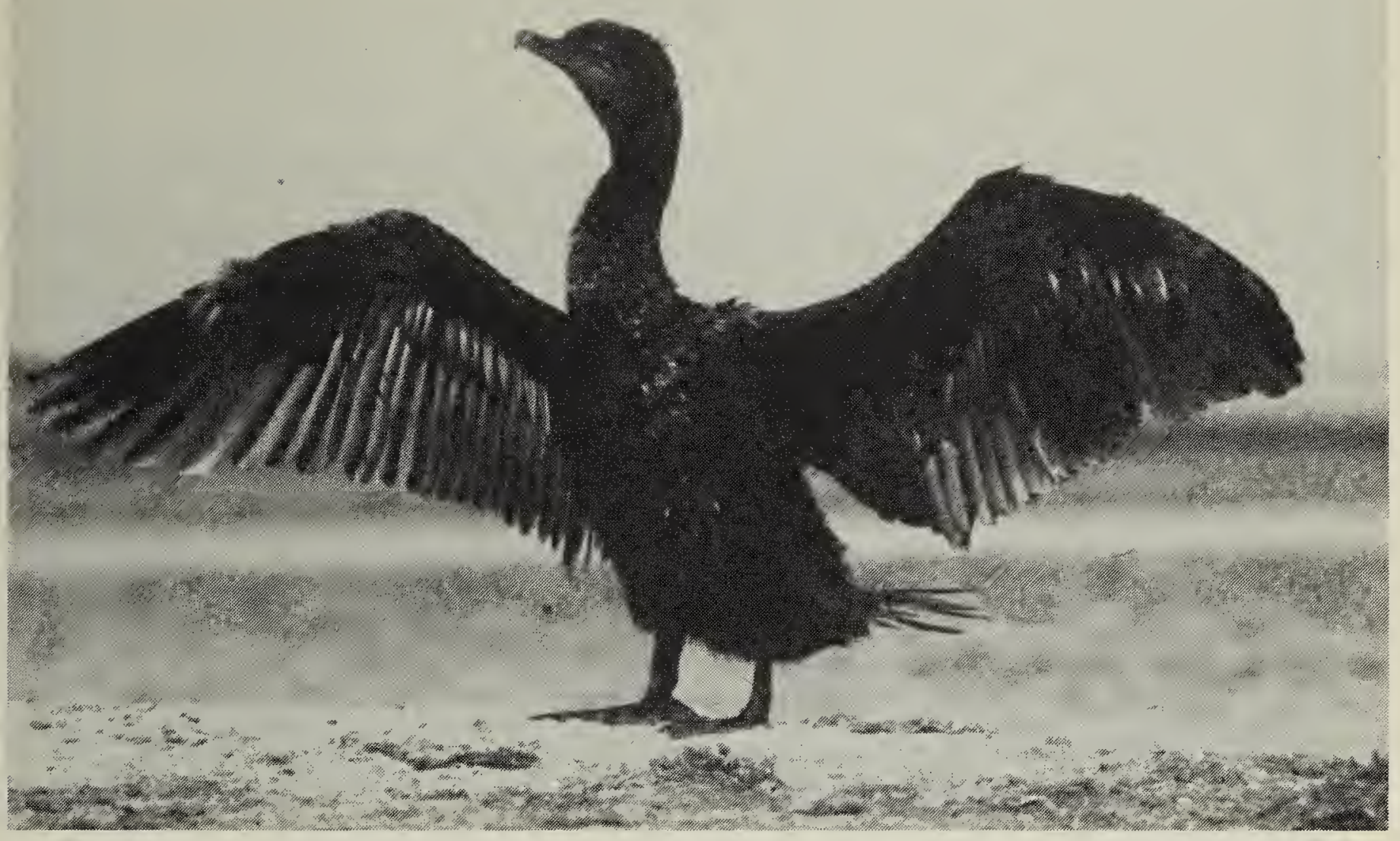

G.W. Beyersbergen

Far from the shore the notes of western grebes reach back, and always the gulls weave their aerial patterns between earth and sky.

- R.D. Symons, 1967.5

Gary Anweiler

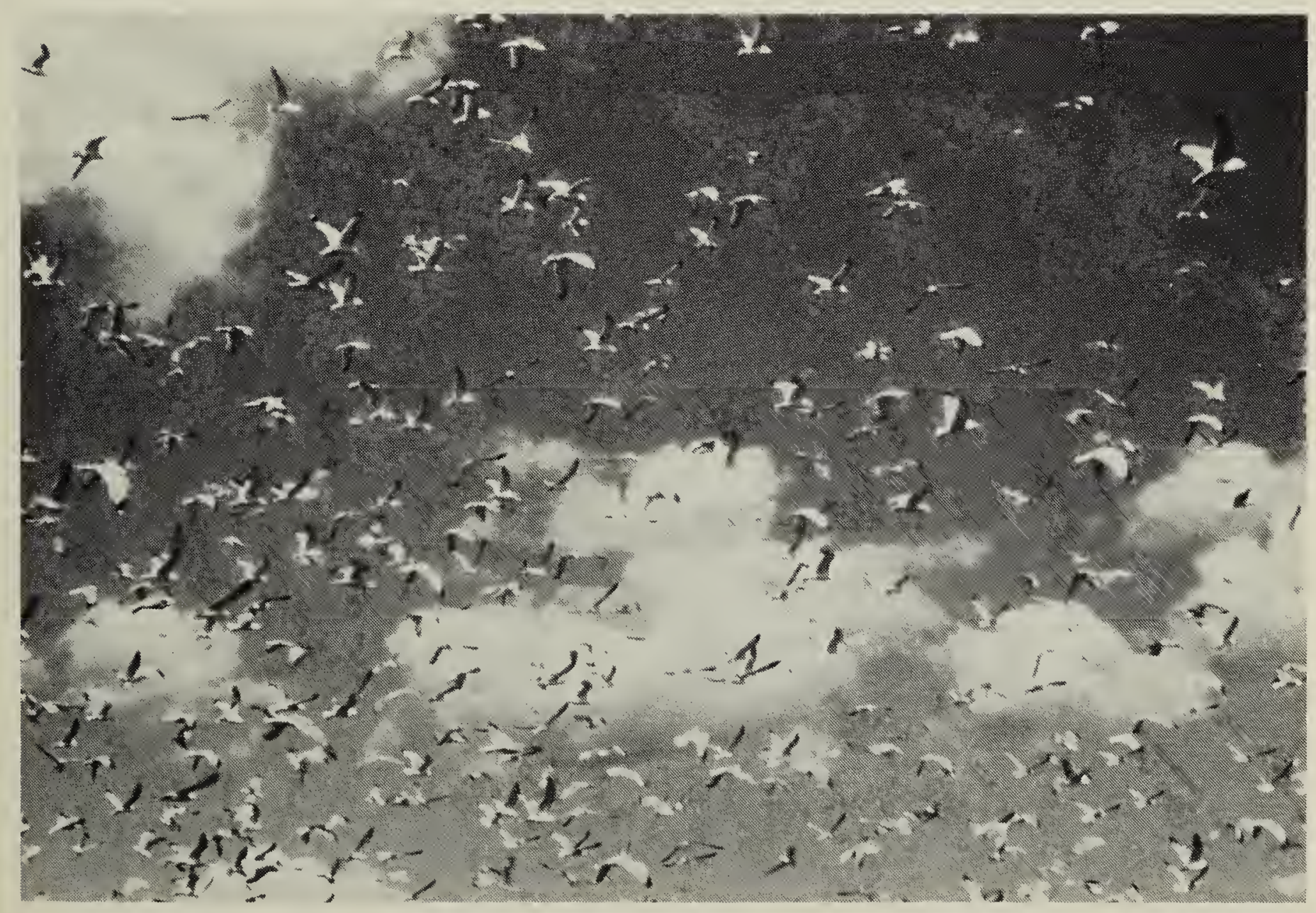




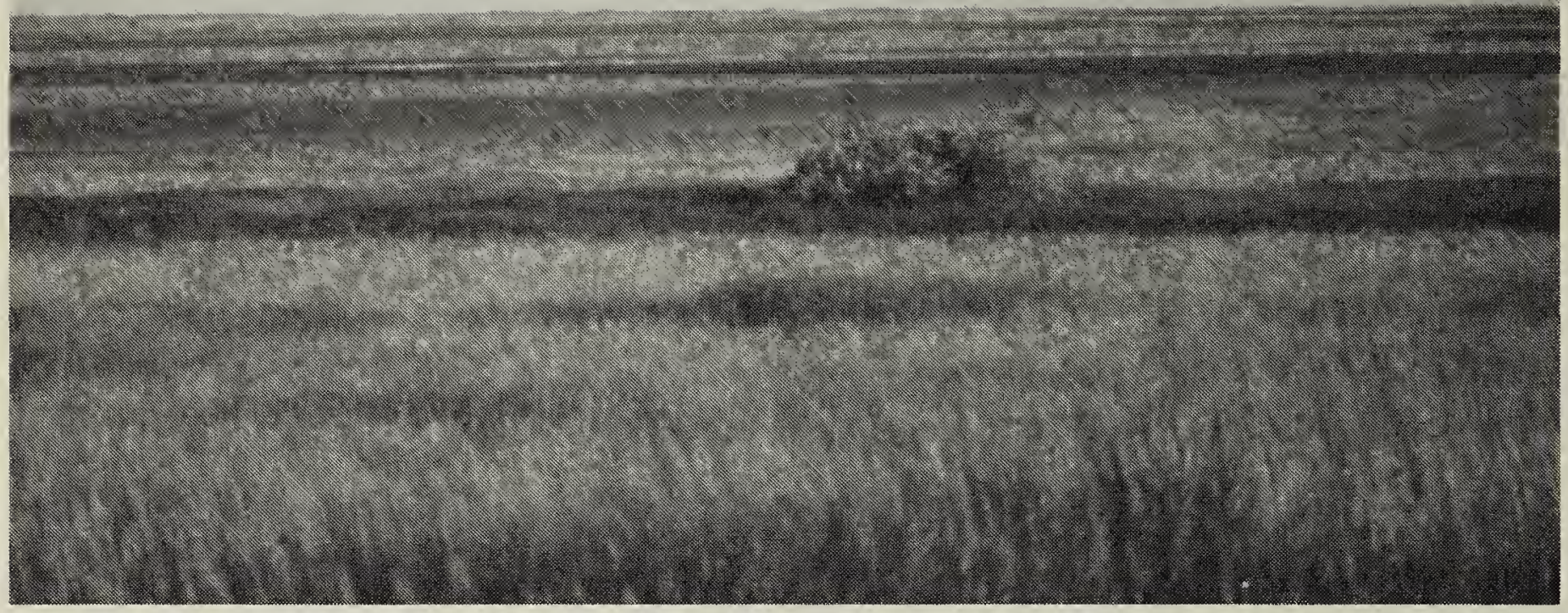

G.W. Beyersbergen

... the grasshopper tribe play their hurdy-gurdys on every hot hillside until the very grass vibrates ...

- R.D. Symons, 1967.5

The Sandhill Crane you are bound to see in fall, if you visit the north end of Last Mountain Lake, that level stretch of sandy, untouched prairie speckled with rose bushes and alive with grasshoppers.

- R.D. Symons, 1967.5

G.W. Beyersbergen

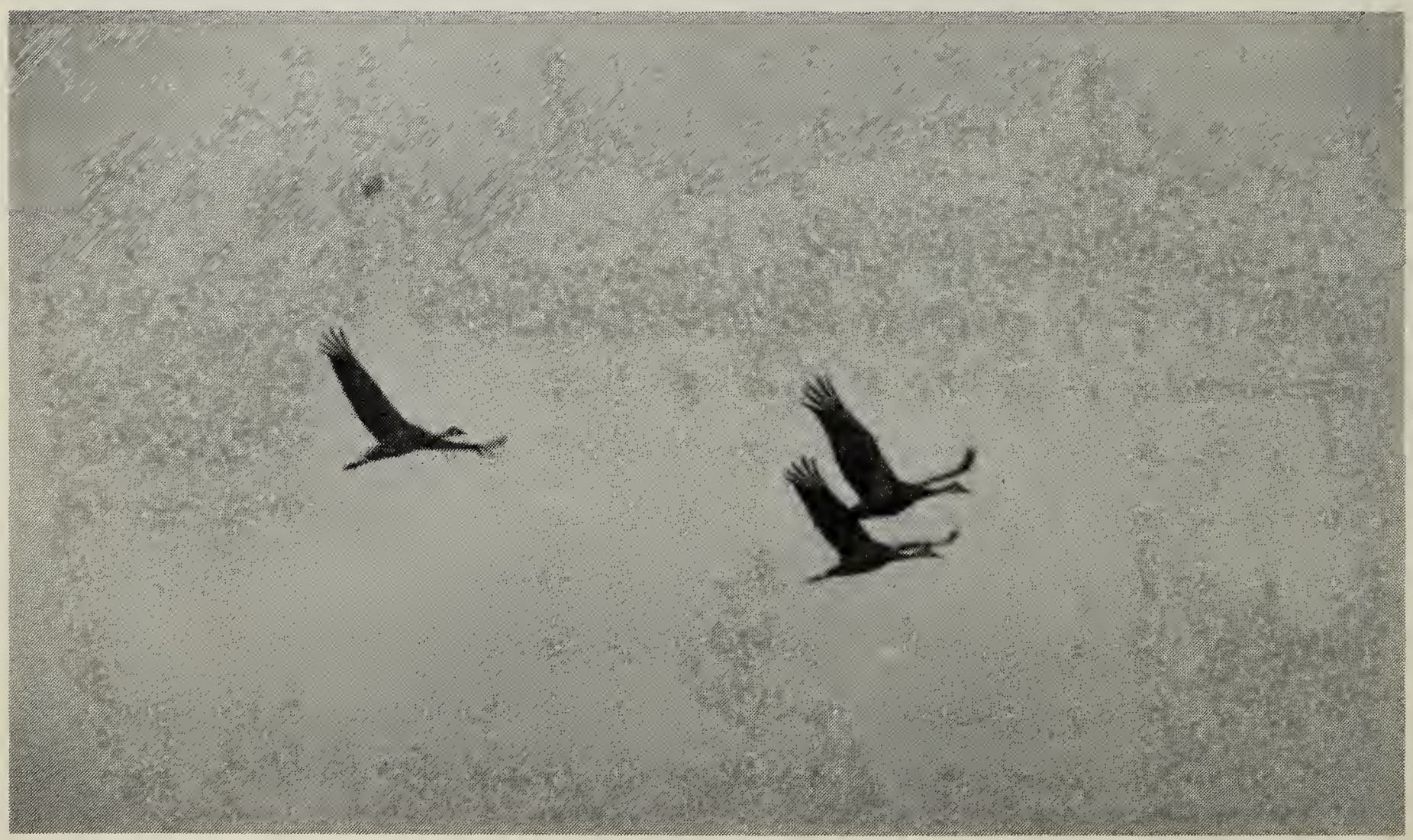

Overleaf: G.W. Beyersbergen 


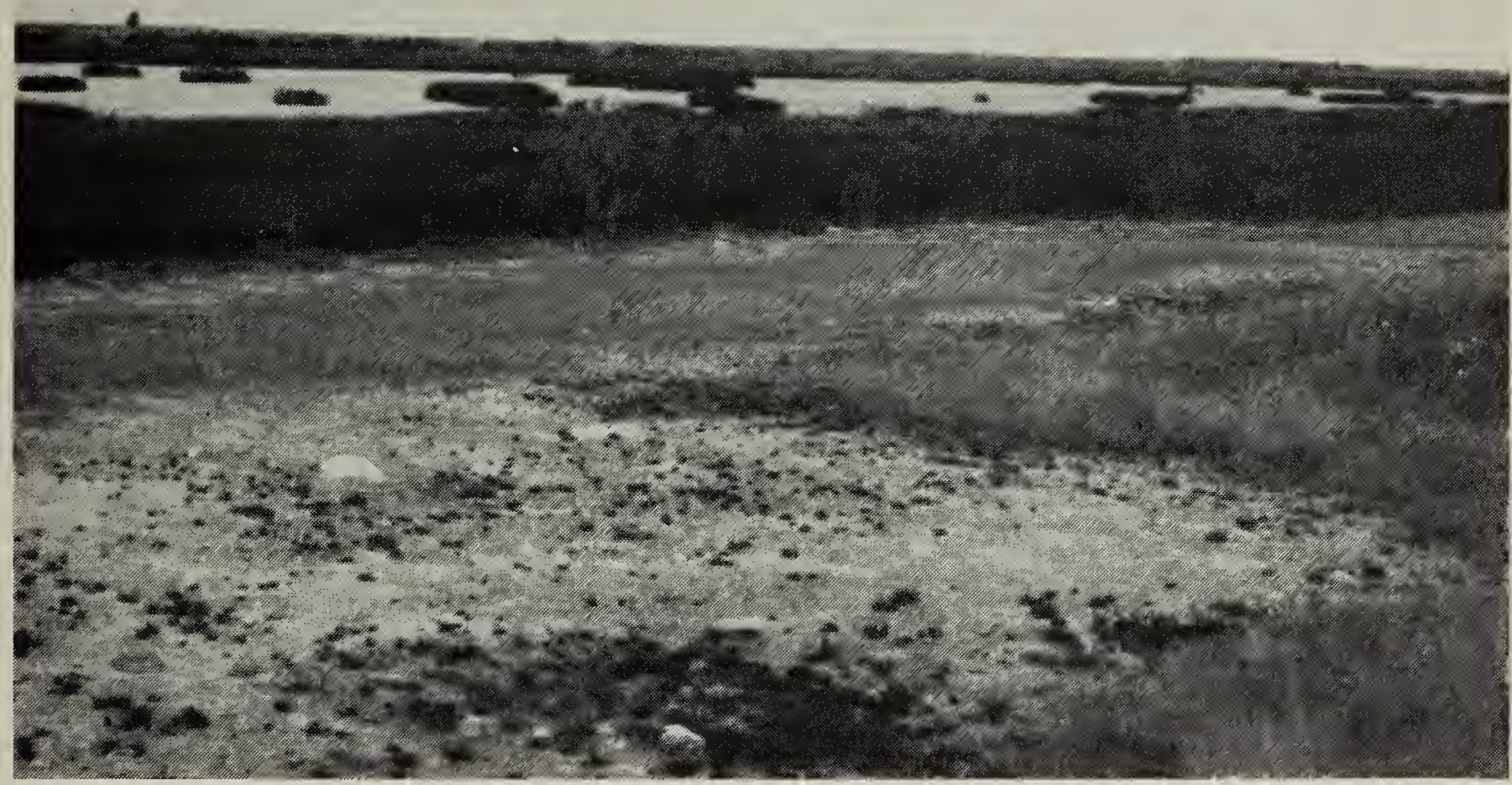

P.S. Taylor

The Wilderness should now no longer be considered as a playground for vandals, or a rich treasure trove to be ruthlessly exploited for the personal gain of a few. . .

- Grey Owl, 1936.'

It lies within our power to preserve for ourselves, but more particularly for posterity for whom we hold it in trust, the wild life of this country.

- C. Gordon Hewitt, 1921.2

G.W. Beyersbergen

1 GREY OWL 1936. Tales of an empty cabin. Lovat Dickson Publ., London. 335 pp.

2 HEWITT, C. GORDON 1921. The conservation of wildlife in Canada. Scribner's Sons, New York. 344 pp.

3 MACOUN, J.A. 1979. Autobiography of John Macoun: Canadian explorer and naturalist 1831-1920. 2nd Edition. Ottawa Field-Naturalists Club. Ottawa.

4 SETON, E.T. 1898. Wild animals I have known. William Briggs Publ., Toronto. 359 pp.

5 SYMONS, R.D. 1967. Hours and the birds: a Saskatchewan record. University of Toronto Press. 224 pp.

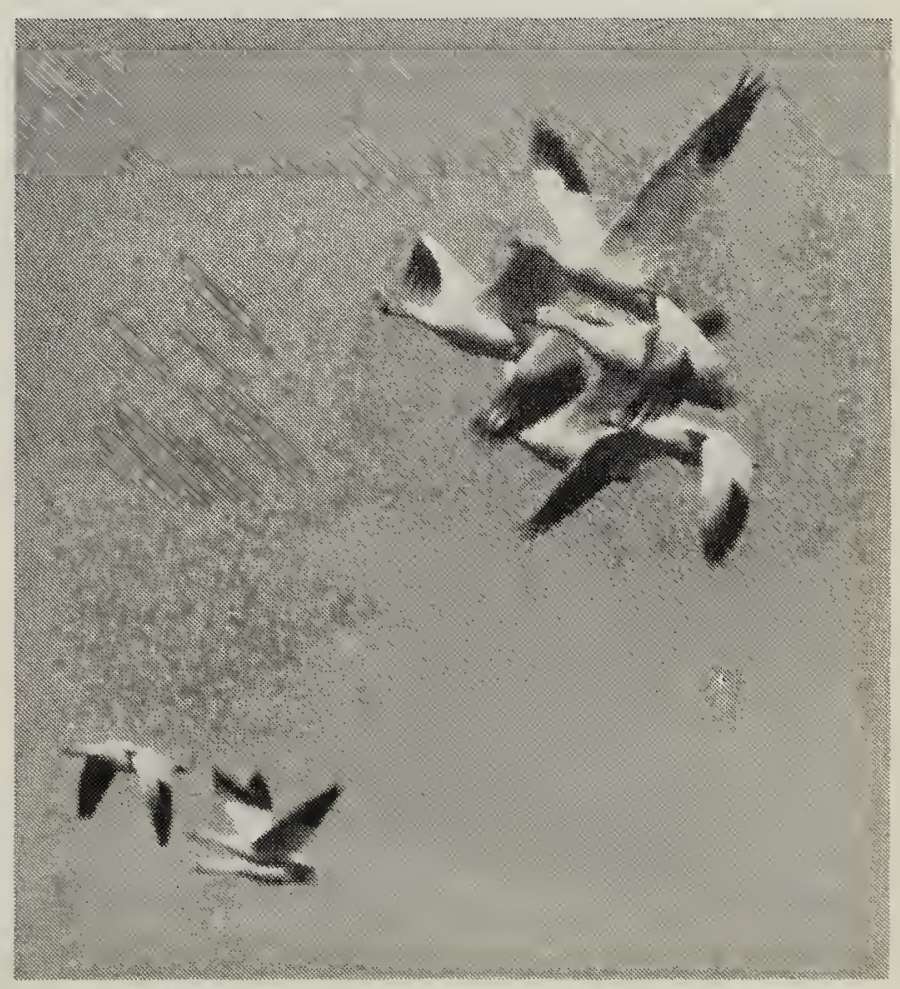




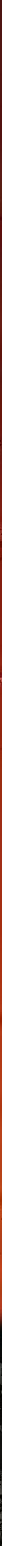

